\title{
Eucalyptus-Palm Kernel Oil Blends: A Complete Elimination of Diesel in a 4-Stroke VCR Diesel Engine
}

\author{
Srinivas Kommana, ${ }^{1}$ Balu Naik Banoth, ${ }^{2}$ and Kalyani Radha Kadavakollu ${ }^{3}$ \\ ${ }^{1}$ Department of Mechanical Engineering, VRSEC, Vijayawada 520 007, India \\ ${ }^{2}$ Department of Mechanical Engineering, JNTU, Hyderabad 500 085, India \\ ${ }^{3}$ Department of Mechanical Engineering, JNTU, Anantapur 515 002, India \\ Correspondence should be addressed to Srinivas Kommana; kommanasrinivas@yahoo.com
}

Received 30 September 2015; Accepted 16 November 2015

Academic Editor: Sergey M. Frolov

Copyright (C) 2015 Srinivas Kommana et al. This is an open access article distributed under the Creative Commons Attribution License, which permits unrestricted use, distribution, and reproduction in any medium, provided the original work is properly cited.

\begin{abstract}
Fuels derived from biomass are mostly preferred as alternative fuels for IC engines as they are abundantly available and renewable in nature. The objective of the study is to identify the parameters that influence gross indicated fuel conversion efficiency and how they are affected by the use of biodiesel relative to petroleum diesel. Important physicochemical properties of palm kernel oil and eucalyptus blend were experimentally evaluated and found within acceptable limits of relevant standards. As most of vegetable oils are edible, growing concern for trying nonedible and waste fats as alternative to petrodiesel has emerged. In present study diesel fuel is completely replaced by biofuels, namely, methyl ester of palm kernel oil and eucalyptus oil in various blends. Different blends of palm kernel oil and eucalyptus oil are prepared on volume basis and used as operating fuel in single cylinder 4-stroke variable compression ratio diesel engine. Performance and emission characteristics of these blends are studied by varying the compression ratio. In the present experiment methyl ester extracted from palm kernel oil is considered as ignition improver and eucalyptus oil is considered as the fuel. The blends taken are PKE05 (palm kernel oil 95 + eucalyptus 05), PKE10 (palm kernel oil 90 + eucalyptus 10), and PKE15 (palm kernel 85 + eucalyptus 15). The results obtained by operating with these fuels are compared with results of pure diesel; finally the most preferable combination and the preferred compression ratio are identified.
\end{abstract}

\section{Introduction}

Continuous rise in fuel price, increase in number of vehicles on road, depletion of petroleum resources, and rapid increase in greenhouse gases are the main reasons for the search of alternative fuels. Up till now many alternative fuels are identified from different resources like vegetables, plants, animal fat, and so forth; these are successfully tested over engine with slight modifications in engine or without any modifications. Alternative fuels are typically produced through the reaction of a vegetable oil or animal fat with alcohol in the presence of the catalyst to produce their esters [1]. These are ecofriendly since these are extracted from plants and animals have the advantage of being biodegradable, less polluting, and renewable [2]. With environmental laws becoming more and more stringent these days, fortunately this renewable source of energy will help to protect the world from the effects of pollution, such as global warming and acid rain [3]. In general, oils extracted from plants are classified into two categories. They are triglyceride oils (TG oils) and terpene oils (light oils). In present study triglyceride oils are used. Triglyceride oils are extracted from plant seeds but eucalyptus oil is taken from the leaves and young twigs of plant. Present study involves two triglyceride oils, namely, eucalyptus oil and methyl ester of palm kernel oil. Eucalyptus oil is prepared from leaves and young twigs of plant, whereas palm kernel oil is prepared from palm kernel. Eucalyptus oil alone cannot replace diesel in diesel engine since the cetane number of eucalyptus oil is insufficient to ignite; but the blended form of eucalyptus oil and methyl ester of palm kernel oil can replace diesel to a maximum extent since the properties of blends are nearer to the properties of diesel fuel. These blends can be used over diesel engine without any further modifications. In the present work performance, emission, 
and combustion characteristics of these biofuel blends are examined over a 4-stroke direct injection diesel engine by varying the compression ratio.

\section{Energy Scenario}

Energy and agriculture are always on the same path, but unfortunately the relation between these has been changing over the time period. Agriculture is the main source of energy and energy is the main input for agriculture production. Until the nineteenth century, animals provided almost all the horse power used for transport and farm equipment and in many parts of the world they still do. Agriculture produces the fuel to feed these animals; two centuries ago, around 20 percent of the agricultural area in the United States of America was used to feed draught animals. At the same time relation over input market increased as agriculture became more dependent on chemical fertilizers extracted from fossils and machinery operated over diesel. Processing and distribution involve higher energy costs, therefore implying a direct and strong impact on agricultural production costs and food costs. The recent advances and researches over biofuels depending on agricultural crops which are used as transport fuels involve the relation between agriculture and energy output markets. The world's total primary energy demand amounts to about 11400 million tons of oil equivalent (Mtoe) per year (IEA, 2012); biomass including forest and agricultural products and organic wastes and residues accounts for 10 percent of this total.

\section{Specification for Biodiesel}

Specifications and standards are the major important parameters for any biodiesel producers, suppliers, and users of biodiesel. Standards are required for the evaluation of safety, risks, environmental problems approval, and warranty of vehicles. Creation of standards shall help expand the market for renewable sources of energy in the world. Generally, standards and codes are developed by examining the existing standards and codes in different countries and then writing standards for the own country. In December 2001, American society of testing and materials (ASTM) issued a specification (D6751) for biodiesel (B100) which is presented in Table 1 and corresponding properties of experimental blends are shown in Tables 2 and 3 and also test rig specifications are depicted in Table 4 . The physical and chemical properties of the test fuels were determined earlier in accordance with the ASTM standards [4].

\section{Experimental Setup}

A single cylinder, four-stroke, constant speed, variable compression ratio, water cooled, direct injection diesel engine is used for the present study. The loading is by means of Eddy current dynamometer. Water cooling system and various sensors and instruments integrated with computer data acquisition. A five-gas analyzer is used to obtain the exhaust gas concentrations in exhaust. Setup enables the

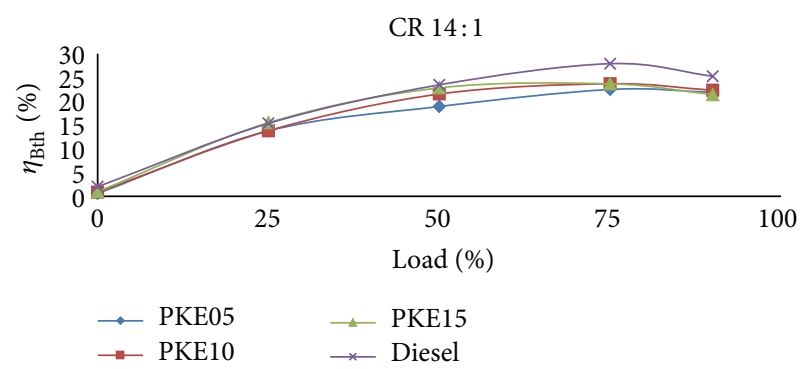

FIGURE 1: Load versus brake thermal efficiency at $14: 1 \mathrm{CR}$.

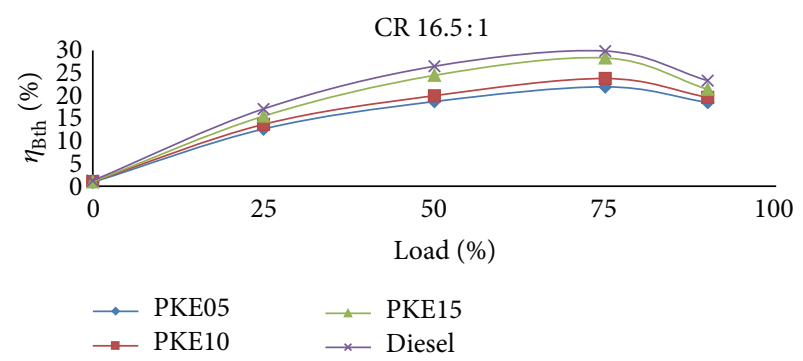

FIGURE 2: Load versus brake thermal efficiency at 16.5:1 CR.

evaluation of performance emissions constituents. Performance parameters include brake thermal efficiency, indicated thermal efficiency, mechanical efficiency, brake specific fuel consumption, and exhaust gas temperature.

\section{Results and Discussion}

5.1. Engine Performance Analysis. The performance of an engine is mainly studied with the help of the operating conditions. The characteristics obtained by operating the single cylinder diesel engine with the blends of palm kernel oil and eucalyptus oil are discussed below. The obtained results were compared with the results obtained when operating with diesel, palm kernel + diesel mixture, and eucalyptus oil + diesel mixture at various compression ratios. Figures 1-21 are used to study various characteristics of engine like brake thermal efficiency, mechanical efficiency, engine outlet temperature, and so forth. Comparison of performance was done for different values of compression ratio [5].

5.1.1. Brake Thermal Efficiency $\left(\eta_{B t h}\right)$, \%. As shown in the graphs (Figures 1, 2, and 3), at all compression ratios, the brake thermal efficiency of diesel is higher than the remaining blends, but at the full load at the same compression ratio the efficiency is nearer to the efficiency obtained by remaining blends.

Next to diesel PKE15 (palm kernel 85 + eucalyptus 15) is higher. This is mainly due to the presence of high volatile eucalyptus oil in the blend used. Eucalyptus oil mainly consists of cineole. Cineole decomposes easily at low temperature; it releases intermediate compounds in a heavy manner as soon as the fuel is injected. The reduced viscosity leads to improved atomization, fuel vaporization, and combustion. Eucalyptus oil's presence increases the ignition delay period 
TABLE 1: ASTM specification (D6751) for biodiesel (B100).

\begin{tabular}{lccc}
\hline Property & ASTM method & Limits & Units \\
\hline Flash point & D93 & 130 min & Degree C \\
Water \& sediment & D2709 & 0.050 max & volume \\
Kinematic viscosity & D445 & $1.9-6.0$ & $\mathrm{Mm}^{2} / \mathrm{sec}^{-0}$ \\
Copper strip corrosion & D130 & Number 3 max & - \\
Cetane & D613 & 47 min & - \\
Cloud point & D2500 & Report & Degree C \\
Carbon residue(100\% sample) & D4530 & 0.050 max & Mg KOH/gm \\
Acid number & D664 & 0.80 max & $\%$ mass \\
Free glycerine & D6584 & 0.020 max &
\end{tabular}

TABle 2: Properties of experimental blends being done at ETA laboratories, Chennai, India.

\begin{tabular}{lccc}
\hline Oils/blends & $\begin{array}{c}\text { Viscosity } \\
(\mathrm{cSt})\end{array}$ & $\begin{array}{c}\text { Calorific value } \\
(\mathrm{Kcal} / \mathrm{Kg})\end{array}$ & $\begin{array}{c}\text { Density } \\
\left(\mathrm{kg} / \mathrm{mm}^{3}\right)\end{array}$ \\
\hline Diesel & 3.25 & 42,700 & 0.84 \\
Palm kernel oil & 4.839 & 37,250 & 0.883 \\
Eucalyptus oil & 2.024 & 43,270 & 0.991 \\
Palm kernel 95 + eucalyptus 05 & 4.246 & 38,158 & 0.892 \\
Palm kernel 90 + eucalyptus 10 & 3.986 & 40,350 & 0.889 \\
Palm kernel 85 + eucalyptus 15 & 3.826 & 41,793 & 0.88 \\
\hline
\end{tabular}

TABle 3: Properties of base fuels.

\begin{tabular}{lccc}
\hline Properties & Diesel & $\begin{array}{c}\text { Eucalyptus } \\
\text { oil }\end{array}$ & $\begin{array}{c}\text { Palm } \\
\text { kernel oil }\end{array}$ \\
\hline Specific gravity, kg/m ${ }^{3}$ & 0.83 & 0.918 & 0.883 \\
Viscosity, cSt & 3.25 & 2.024 & 4.839 \\
Flash point, ${ }^{\circ} \mathrm{C}$ & 74 & 53 & 167 \\
Lower heating value, $\mathrm{KJ} / \mathrm{Kg}$ & 42700 & 43270 & 37,250 \\
Autoignition temperature, ${ }^{\circ} \mathrm{C}$ & 250 & $300-330$ & $400-450$ \\
\hline
\end{tabular}

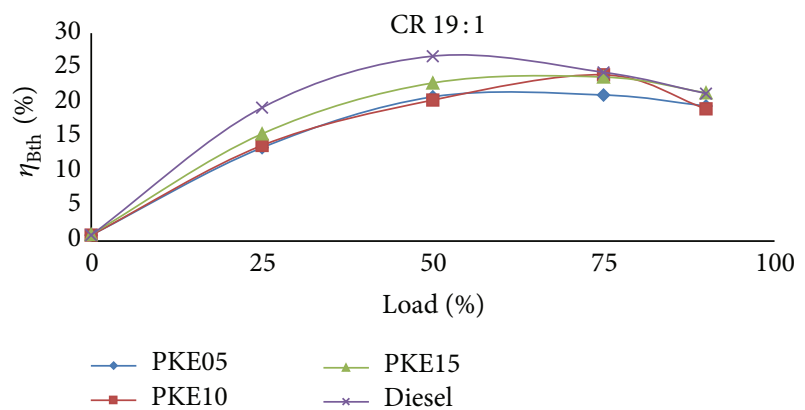

Figure 3: Load versus brake thermal efficiency at 19:1 CR.

and it causes the heavy accumulation of fuel which results in large heat release and higher brake thermal efficiency and high cylinder pressure.

5.1.2. Mechanical Efficiency $\left(\eta_{m e}\right)$. As shown in the graphs (Figures 4, 5, and 6), the mechanical efficiency of diesel is very high at compression ratio 14 when compared to the remaining experimental blends at all loads.
TABLE 4: Test rig specifications.

\begin{tabular}{ll}
\hline Engine & $\begin{array}{l}\text { Type: single cylinder, four-stroke diesel, } \\
\text { water cooled }\end{array}$ \\
\hline Rated power & $3.7 \mathrm{~kW}$ at $1500 \mathrm{rpm}$ \\
\hline Stroke & $110 \mathrm{~mm}$ \\
\hline Bore & $87.5 \mathrm{~mm}$ \\
\hline $\begin{array}{l}\text { Compression } \\
\text { ratio range }\end{array}$ & 12 to 24 \\
\hline $\begin{array}{l}\text { Dynamometer } \\
\text { Lype eddy current, water cooled, with } \\
\text { loading unit }\end{array}$ \\
\hline $\begin{array}{l}\text { Load sensor } \\
\text { Piezosensor }\end{array}$ & $\begin{array}{l}\text { Load cell, type strain gauge, range } \\
0-50 \text { Kg }\end{array}$ \\
\hline $\begin{array}{l}\text { Air flow } \\
\text { transmitter }\end{array}$ & Range 5000 psi, with low noise cable \\
\hline $\begin{array}{l}\text { Pressure transmitter, range 0-250 mm } \\
\text { Software }\end{array}$ & $\begin{array}{l}\text { EngineSoftLV" Engine performance } \\
\text { analysis software }\end{array}$ \\
\hline $\begin{array}{l}\text { Exhaust gas } \\
\text { analyzer }\end{array}$ & \begin{tabular}{l} 
Make: Indus Scientific, five-gas analyzer \\
\hline
\end{tabular}
\end{tabular}

At compression ratios 16.5:1 and 19:1 the mechanical efficiency is equal for all the experimental fuels and diesel at all the loads. Comparatively, at compression ratio 19:1 CR, full load efficiency for PKE15 is higher than remaining experimental blends. Mechanical efficiency is the result of both brake thermal efficiency and indicated thermal efficiency. The brake thermal efficiency and indicated thermal efficiency of diesel are higher than remaining blends. Next to the diesel PKE15 blend is having higher efficiency. Mechanical 


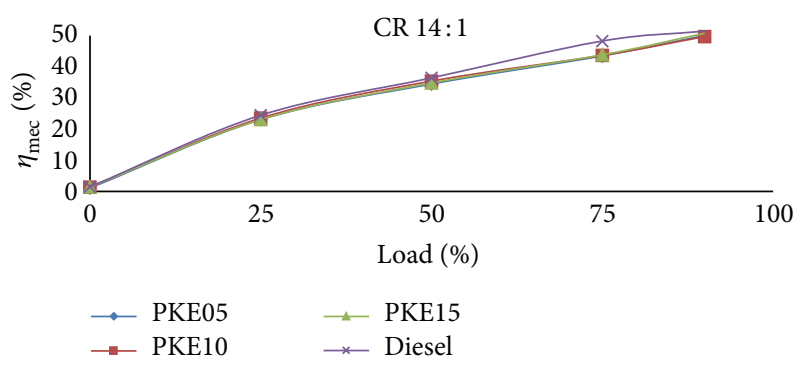

FIGURE 4: Load versus mechanical efficiency at $14: 1 \mathrm{CR}$.

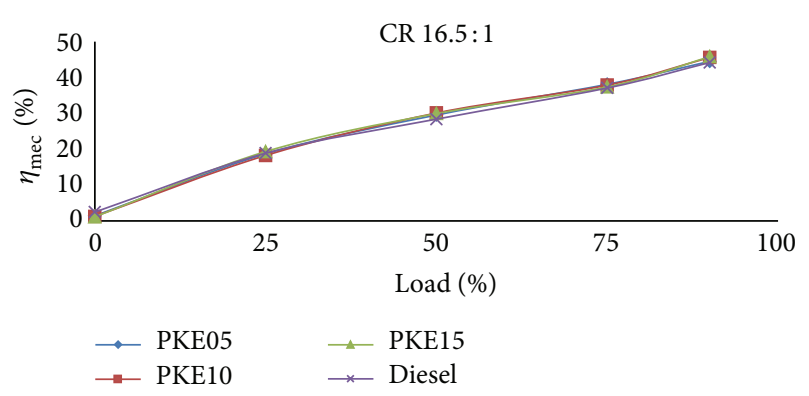

FIGURE 5: Load versus mechanical efficiency at 16.5:1 CR.

efficiency of diesel and the experimental blends are almost equal with a slight variation.

5.1.3. Exhaust Gas Temperature. As shown in the graphs (Figures 7, 8, and 9) the exhaust temperature of diesel is lower than the remaining experimental blends. This is mainly due to the presence of eucalyptus oil in the blends which has lower cetane number and high percentage of oxygen which leads to longer ignition delay and rapid combustion which results in higher temperature and high cylinder pressure. Next to diesel PKE05 is having lower exhaust temperature at all the compression ratios. It has lower temperature compared to remaining blends since the quantity of eucalyptus oil present in this blend is smaller than remaining blends.

5.2. Emission Analysis. From these reports, the effects of biofuel on regulated emissions were studied [6].

5.2.1. Hydrocarbon (HC) Emissions. As shown in the graphs (Figures 10,11, and 12) the hydrocarbon emissions of diesel are higher than all the experimental blends. At all compression ratios and different loads diesel is having the high emission of hydrocarbons. In our present experimental blends PKE05 is having higher $\mathrm{HC}$ emissions. $\mathrm{HC}$ emissions for biofuels are low because of the complete combustion of the fuel because of more availability of oxygen in biodiesel. As the ignition period increases due to the lower cetane number, at some areas of the combustion chamber the mixture becomes too lean which leads to the lower HC emissions.

5.2.2. Carbon Dioxide $\left(\mathrm{CO}_{2}\right)$ Emissions. As shown in the graphs (Figures 13, 14, and 15) the carbon dioxide emissions of all the experimental fuels are higher when compared to

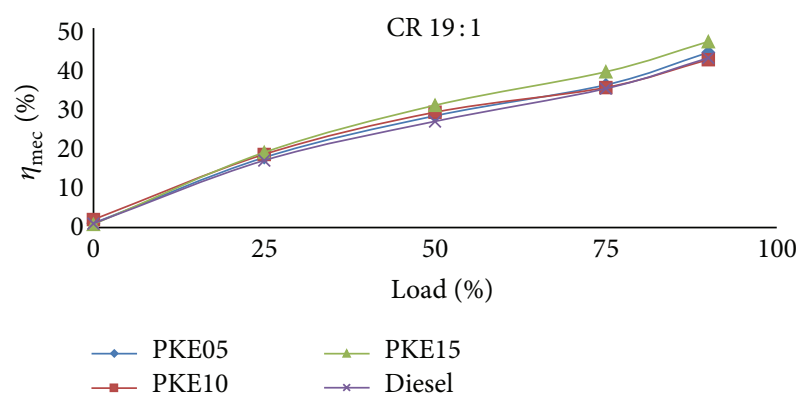

FIGURE 6: Load versus mechanical efficiency at 19:1 CR.

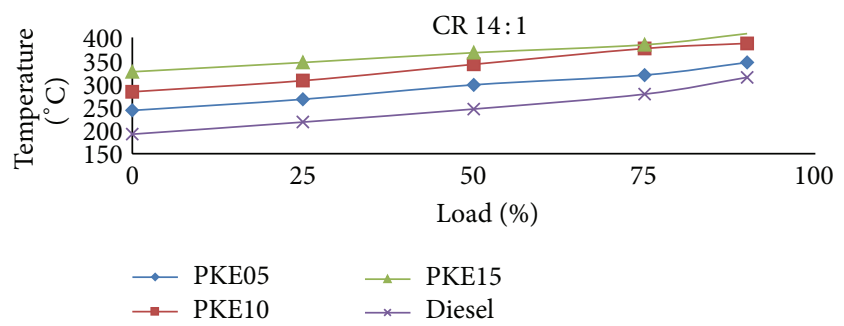

Figure 7: Load versus exhaust gas temperature at 14:1 CR.

diesel. This is mainly because of the oxygen enrichment in the eucalyptus oil and addition of palm kernel oil leads to the oxidation of $\mathrm{CO}$ produced during the exhaust process. Rather, diesel PKE05 is having lesser emissions in the present experimental fuels.

5.2.3. Oxides of Nitrogen Emissions. As shown in the graphs (Figures 16, 17, and 18) nitrous oxide emissions of diesel are lesser when compared to experimental fuels. This is mainly because of the heavy existence of oxygen in palm kernel oil and further more existence of oxygen in eucalyptus oil and elevated temperatures derived because of complete combustion. $\mathrm{NO}_{x}$ is recorded higher than diesel fuel due to high oxygen content in biodiesel and lower cetane number (CN) of eucalyptus oil, also lengthening the ignition delay period [7].

5.2.4. Oxides of Sulphur Emissions. As shown in the graphs (Figures 19, 20, and 21) sulphur oxide emission of diesel is high at all compression ratios at all the loads. In our experimental fuels PKE05 is having higher emissions and PKE15 is having lower emissions.

\section{Conclusion}

The effective compression ratio can be fixed based on the experimental results obtained in the engine since the findings of the present research work infer that the biofuel obtained from palm kernel oil and eucalyptus oil blend is a promising alternative fuel for four-stroke VCR engine [8]. 


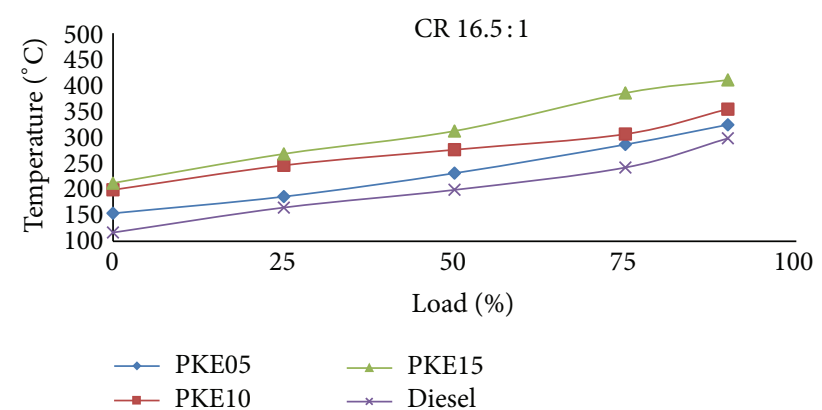

Figure 8: Load versus exhaust gas temperature at 16.5:1 CR.

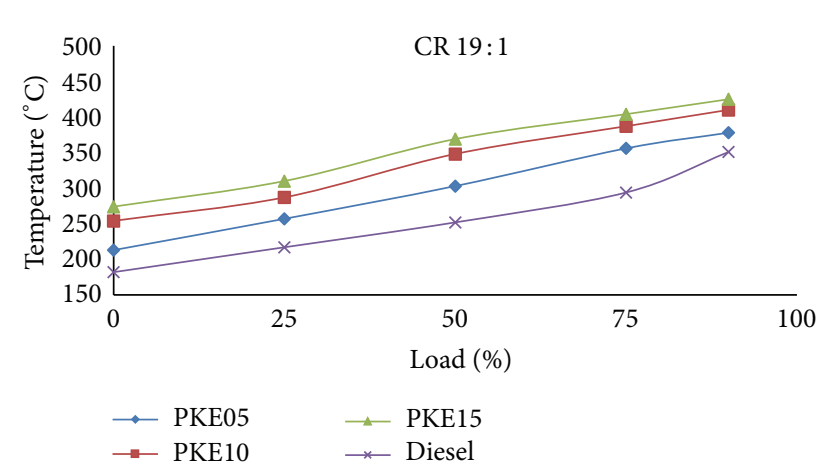

FIGURE 9: Load versus exhaust gas temperature at 19:1 CR.

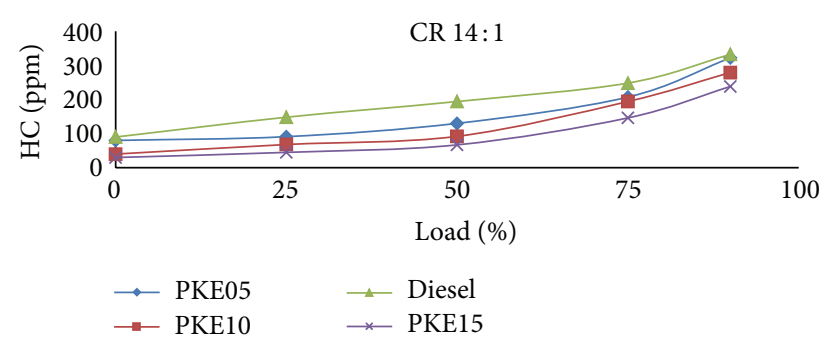

FIGURE 10: Load versus HC emissions at 14:1 CR.

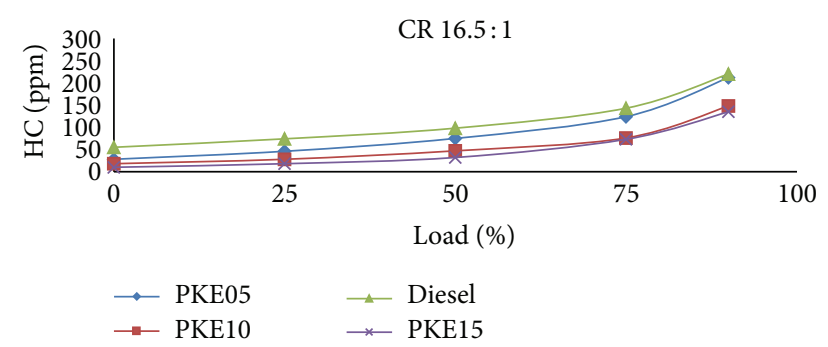

FIGURE 11: Load versus HC emissions at 16.5:1 CR.

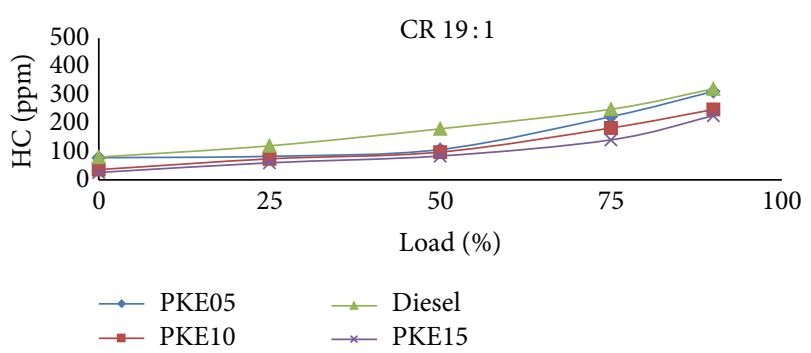

FIGURE 12: Load versus HC emissions at 19:1 CR.

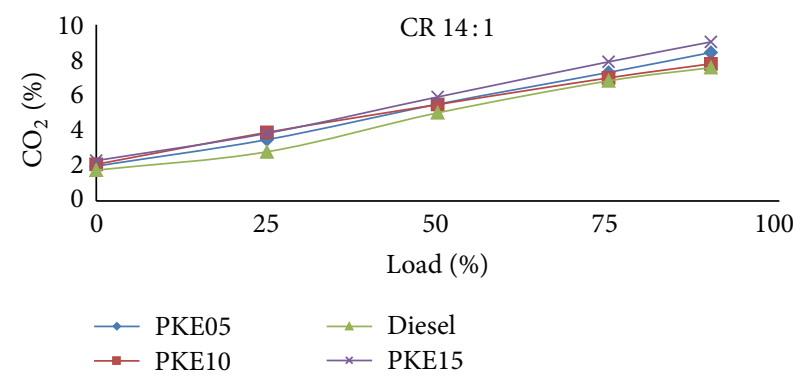

FIGURE 13: Load versus $\mathrm{CO}_{2}$ emissions at $14: 1 \mathrm{CR}$.

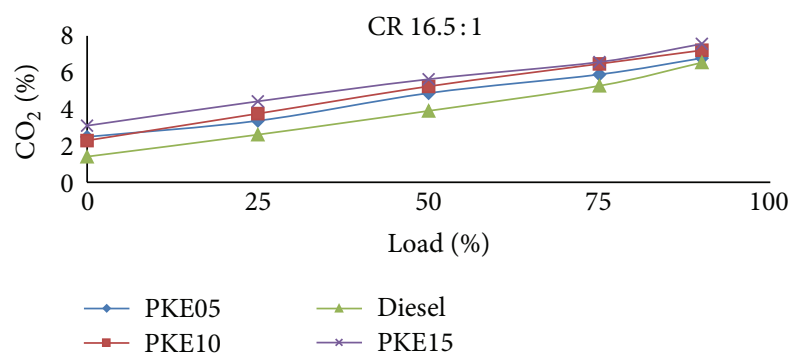

Figure 14: Load versus $\mathrm{CO}_{2}$ emissions at $16.5: 1 \mathrm{CR}$.

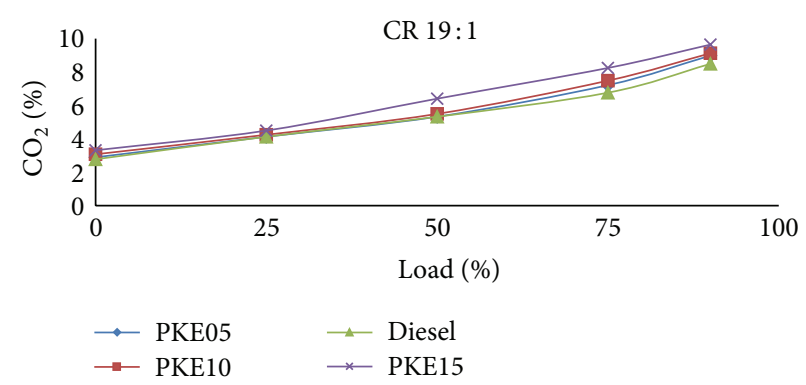

FIGURe 15: Load versus $\mathrm{CO}_{2}$ emissions at 19:1 CR.

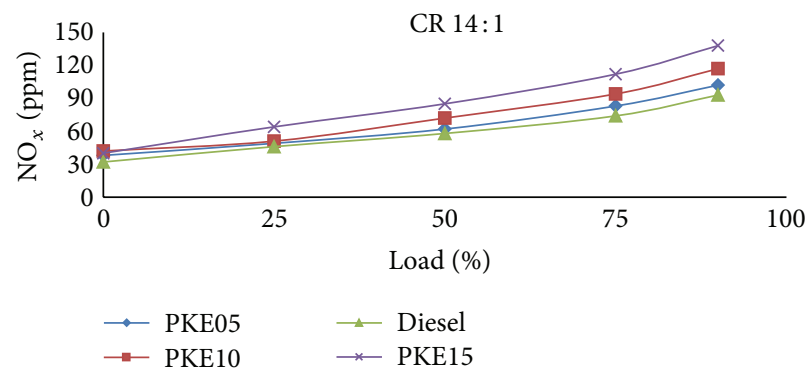

FIGURE 16: Load versus $\mathrm{NO}_{x}$ emissions at $14: 1 \mathrm{CR}$.

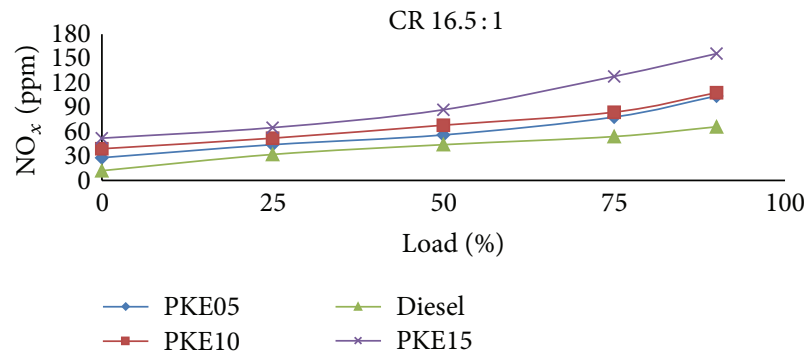

Figure 17: Load versus $\mathrm{NO}_{x}$ emissions at 16.5:1 CR. 


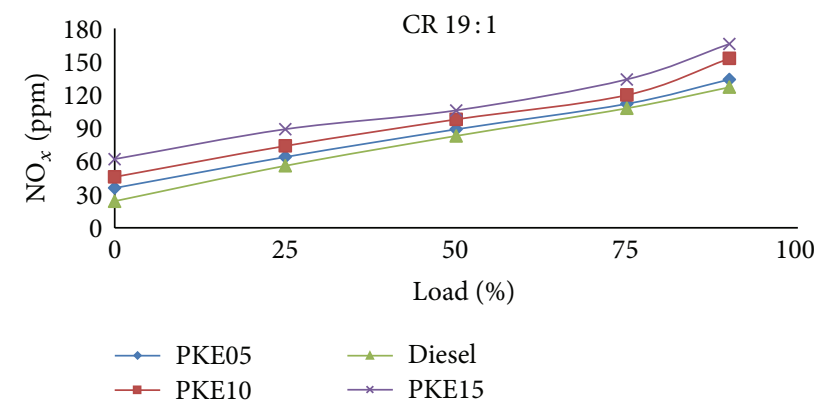

FIGURE 18: Load versus $\mathrm{NO}_{x}$ emissions at 19:1 CR.

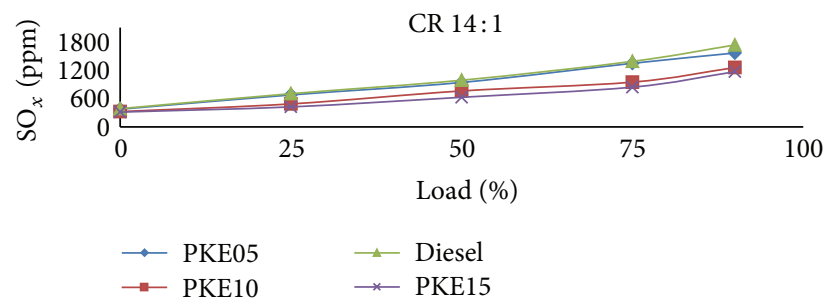

FIGURE 19: Load versus $\mathrm{SO}_{x}$ emissions at 14:1 CR.

\subsection{Performance Analysis}

(1) Brake thermal efficiency of all the considered blends at all the compression ratios for minimum loads is equal; as the load increases efficiency increases and diesel has higher efficiency compared to remaining blends. Compared to remaining compression ratios, at CR $16.5: 1$, maximum efficiency is obtained but as the load approaches full load the efficiency gradually decreases.

(2) Mechanical efficiency is higher at compression ratio $14: 1$ when compared with remaining compression ratios. At CR 14:1 the efficiency of diesel is higher but at remaining compression ratios with minute variations PKE15 (palm kernel 85 + eucalyptus 15) it has higher mechanical efficiency when compared to diesel.

(3) Exhaust gas temperature of diesel is lower than all the considered experimental fuels. Comparatively next to diesel PKE05 has lower exhaust gas temperature.

\subsection{Emission Analysis}

(1) HC emissions are high for PKE05 compared to the remaining experimental blends. By looking at overall results, at compression ratio $14: 1, \mathrm{HC}$ emissions are high for all the blends. Compared to all the considered blends, PKE15 emits lower HC emissions than diesel at all the compression ratios.

(2) Carbon dioxide emissions are higher at compression ratio 19:1 for all the considered blends. As the compression ratio increases $\mathrm{CO}_{2}$ emissions increase.

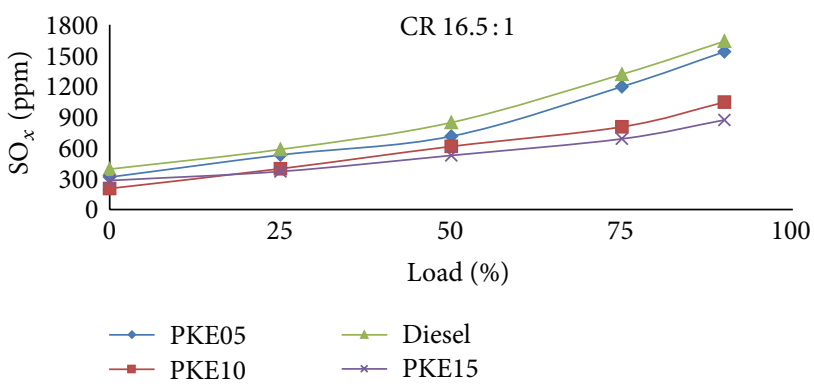

Figure 20: Load versus $\mathrm{SO}_{x}$ emissions at 16.5: $1 \mathrm{CR}$.

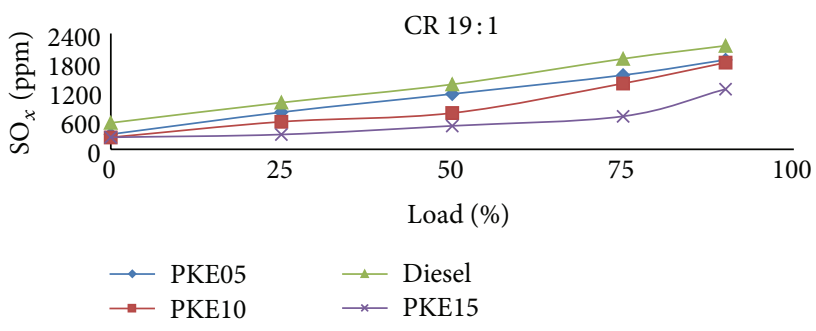

Figure 21: Load versus $\mathrm{SO}_{x}$ emissions at 19:1 CR.

At Cr 14:1 lower $\mathrm{CO}_{2}$ emissions are observed. As the load increases the emission increases. PKE15 has higher emissions compared to all the considered fuels.

(3) At minimum loads the oxygen emissions are high; as the load increases oxygen emissions decrease. Oxygen emitted by PKE10 (palm kernel 90 + eucalyptus 10) is almost equal to the oxygen content emitted by diesel at all the loads for all the compression ratios. PKE15 emits the least oxygen emissions.

(4) As the compression ratio increases the emissions increase. Diesel emits higher $\mathrm{SO}_{x}$ emissions when compared to the considered experimental blends.

(5) As the compression ratio increases $\mathrm{NO}_{x}$ emissions increase. At CR 19:1 $\mathrm{NO}_{x}$ emissions are higher; as the load increases $\mathrm{NO}_{x}$ emissions increase. For PKE15 (palm kernel $85+$ eucalyptus 15) $\mathrm{NO}_{x}$ is higher than remaining experimental fuels.

The results proved that the blending of palm kernel oil with eucalyptus oil can be used as an alternative fuel in diesel engine by complete elimination of diesel. The emissions and performance are of considerable range for all blends especially for PKE15 blend. It can be concluded that palm kernel 85 + eucalyptus 15 can be used in diesel engine without any major modifications to the engine.

\section{Conflict of Interests}

The authors declare that there is no conflict of interests regarding the publication of this paper. 


\section{References}

[1] R. Prakash, S. P. Pandey, S. Chatterji, and S. N. Singh, "Emission analysis of CI engine using rice bran oil and their esters," Journal of Engineering Research and Studies, vol. 2, pp. 173-178, 2011.

[2] S. O. Eze, M. O. Ngadi, J. S. Alakali, and C. J. Odinaka, "Quality assessment of biodiesel produced from after fry waste Palm Kernel Oil (PKO)," European Journl of Natural and Applied Science, vol. 1, no. 1, pp. 38-46, 2013.

[3] A. S. Rocha, M. Veerachamy, V. K. Agrawal, and S. K. Gupta, "Jatropha liquid gold-the alternative to diesel," in Proceedings of the 1st WIETE Annual Conference on Engineering and Technology Education, pp. 91-96, Pattaya, Thailand, February 2010.

[4] B. P. Anand, C. G. Saravanan, and C. A. Srinivasan, "Performance and exhaust emission of turpentine oil powered direct injection diesel engine," Renewable Energy, vol. 35, no. 6, pp. 1179-1184, 2010.

[5] M. Venkatraman and G. Devaradjane, "Experimental investigation of effect of compression ratio, injection timing and injection pressure on the performance of a CI engine operated with diesel-pungam methyl ester blend," in Proceedings of the Frontiers in Automobile and Mechanical Engineering (FAME '10), pp. 117-121, Chennai, India, November 2010.

[6] J. Xue, T. E. Grift, and A. C. Hansen, "Effect of biodiesel on engine performances and emissions," Renewable and Sustainable Energy Reviews, vol. 15, no. 2, pp. 1098-1116, 2011.

[7] M. S. Shehata, "Emissions, performance and cylinder pressure of diesel engine fuelled by biodiesel fuel," Fuel, vol. 112, pp. 513522,2013

[8] M. T. Raj and M. K. K. Kandasamy, "Tamanu oil-an alternative fuel for variable compression ratio engine," International Journal of Energy and Environmental Engineering, vol. 3, no. 1, article 18, 2012.

[9] B. T. Tompkins, H. Song, J. A. Bittle, and T. J. Jacobs, "Efficiency considerations for the use of blended biofuel in diesel engines," Applied Energy, vol. 98, pp. 209-218, 2012.

[10] B. S. Chauhan, N. Kumar, H. M. Cho, and H. C. Lim, "A study on the performance and emission of a diesel engine fueled with Karanja biodiesel and its blends," Energy, vol. 56, pp. 1-7, 2013. 

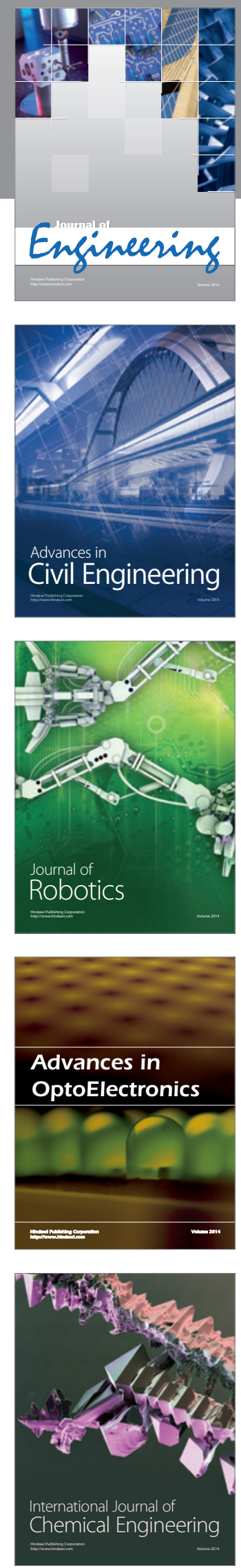

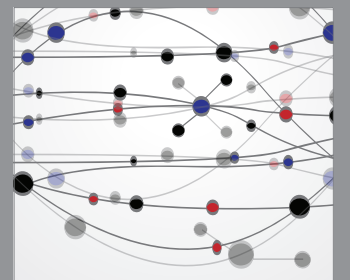

The Scientific World Journal
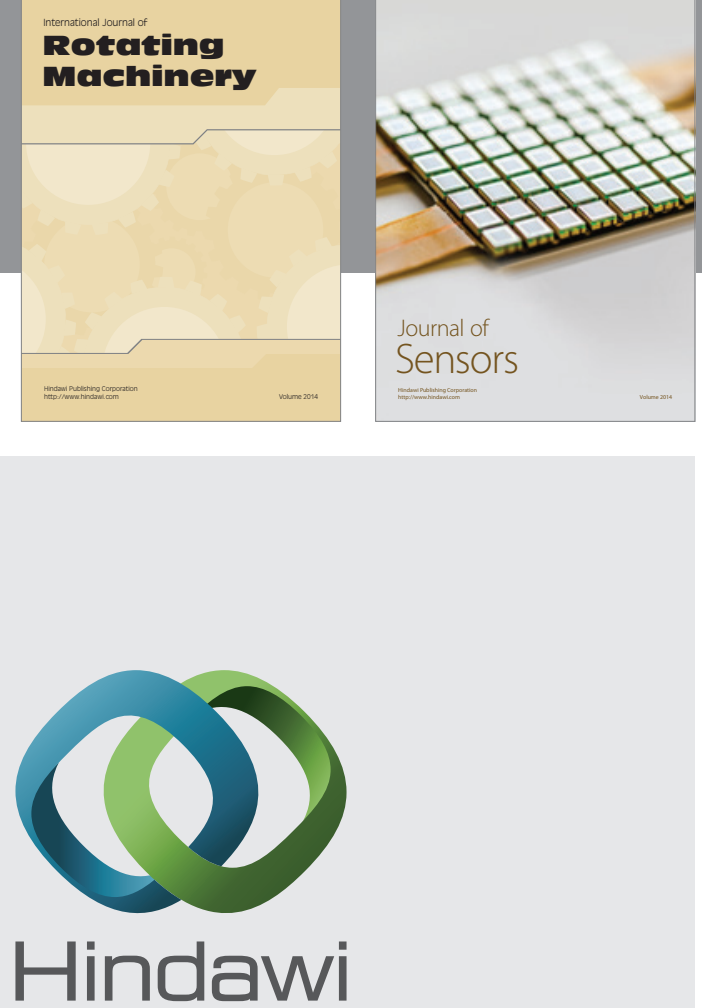

Submit your manuscripts at http://www.hindawi.com
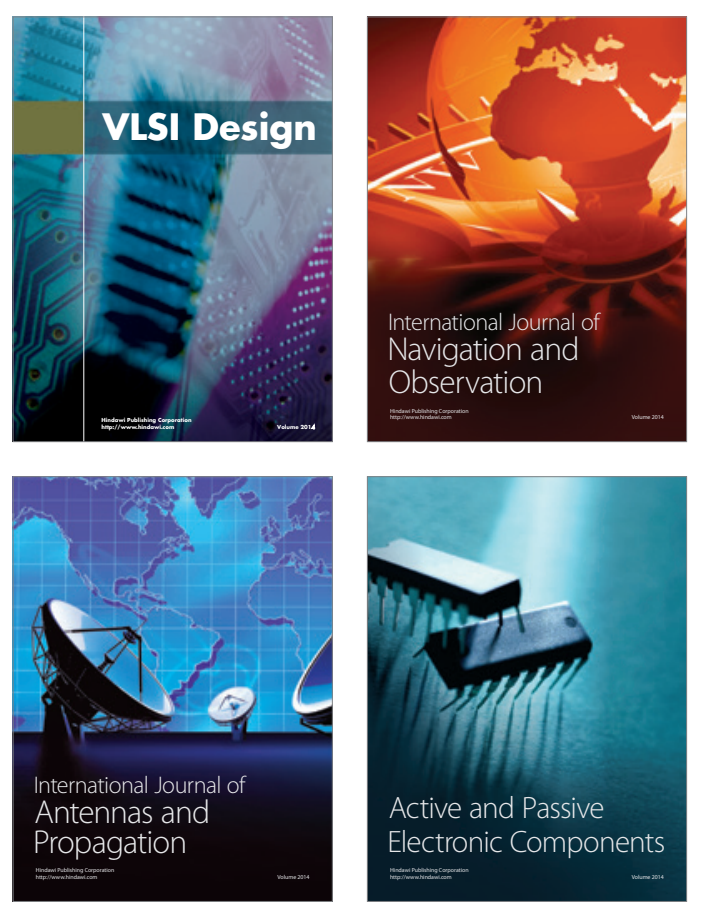
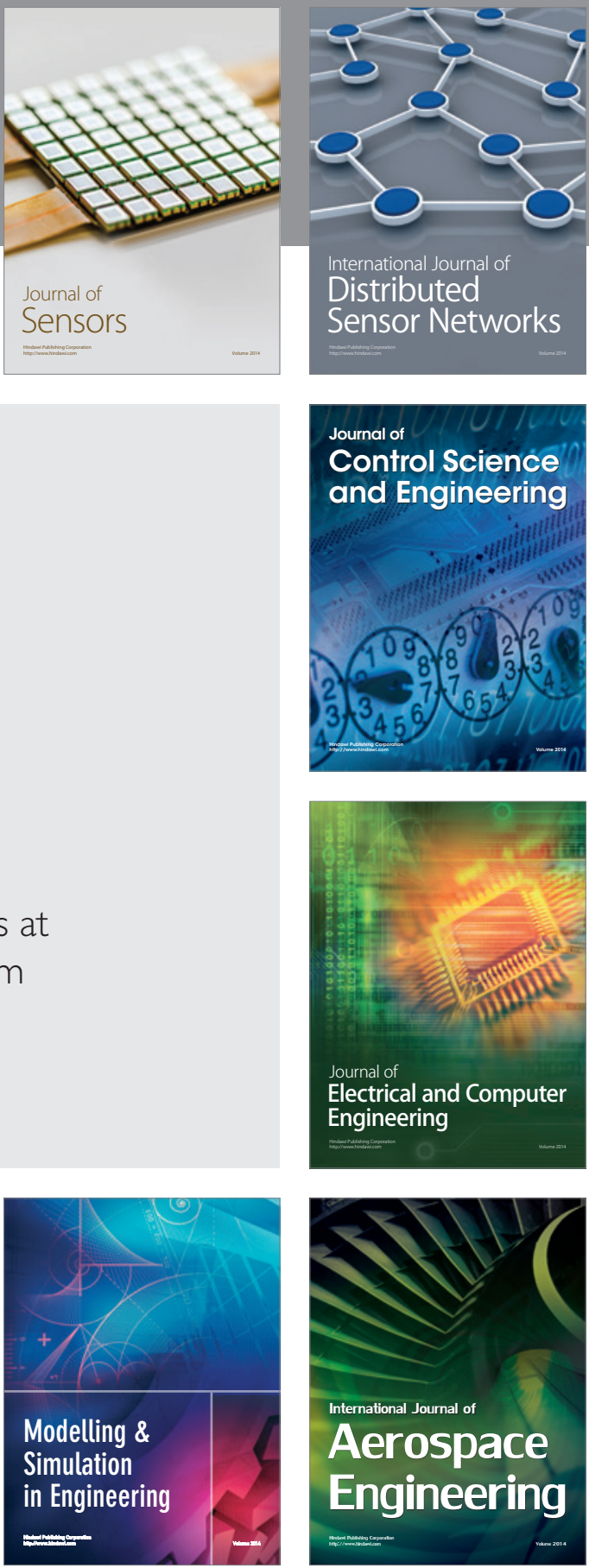

Journal of

Control Science

and Engineering
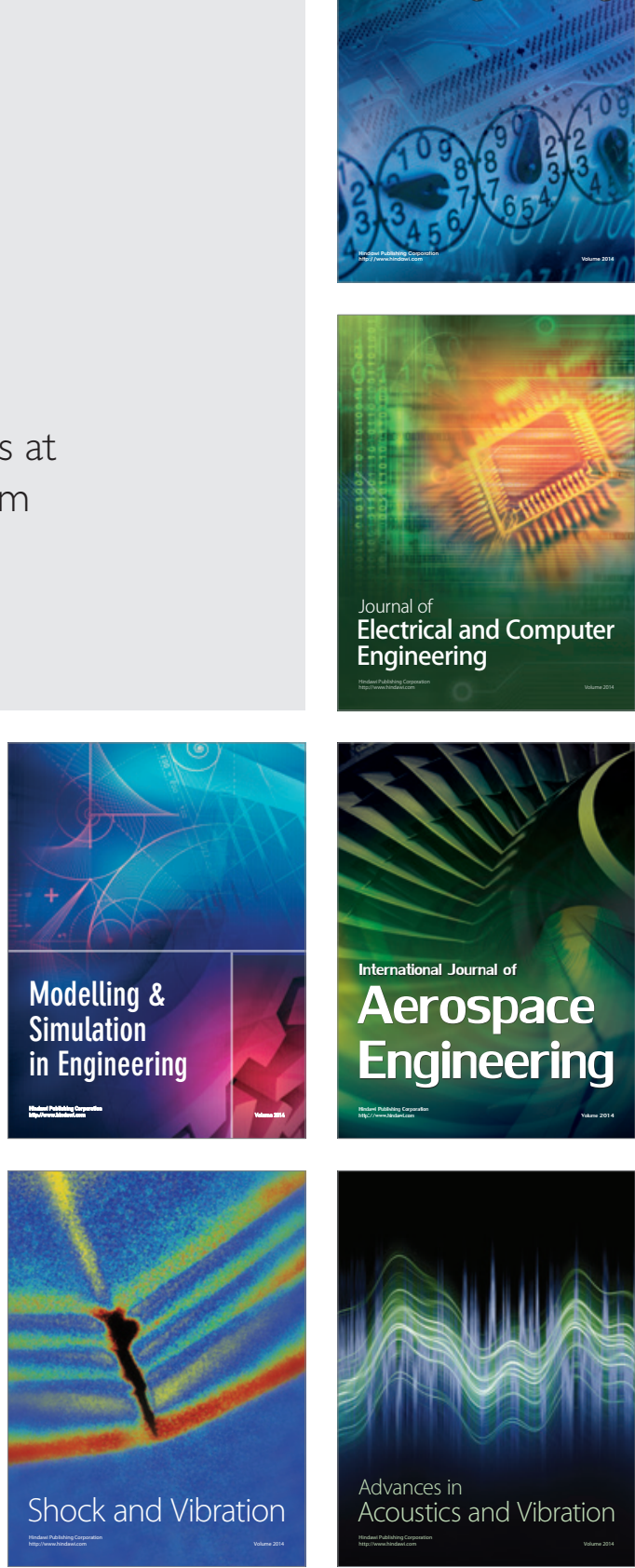